\title{
An Empirical Study on the Quality of Internal Control and the Financing Cost of Enterprises
}

\author{
Aolin Liu \\ School of Management, Wuhan University of Technology, Wuhan 430070, China \\ 494018558@qq.com
}

Keywords: Internal control quality; Debt financing cost; Equity financing cost

\begin{abstract}
The internal control can transfer assets to the outside world security situation of the efficiency of corporate management and other signals, its essence is a guarantee for the normal operation and the control mechanism of enterprises development, it can help enterprises to achieve lower transaction costs. This article uses Internal control index from Shenzhen Dibo Enterprise Risk Management Technology Co. Ltd., internal control and risk management database,through descriptive statistics, Pearson test and multiple regression analysis the influence of internal control quality on the financing cost of enterprise is investigated. The results show that the better the quality of internal control, the lower the cost of corporate finance.
\end{abstract}

\section{Introduction}

With the continuous development and improvement of China's securities market, the environment of Listed Companies in China has undergone tremendous changes.Under the background, the external demand of the company wants the company to provide more timely, more transparent, more reliable internal control information to reduce the adverse effects caused by asymmetric information,the internal demand of the enterprise, it is hoped that through the construction of internal control to improve the credibility of enterprises, the transfer of a good image, expand the source of financing, which has become an urgent requirement of the majority of investors.As an important source of financing, the high quality of internal control can help enterprises to obtain the support of investors and creditors?This requires us to explore the relationship between internal control quality and financing cost.

\section{The Relationship between Internal Control Quality and Corporate Financing Cost}

The Relationship between internal Control Quality and Equity Financing Cost. For an enterprise, the possibility of financing lies in the confidence of investors. To change the views of investors on the listed companies, internal control plays a very critical role in this.Healy and Palepu (2001) considered, The higher the quality of information disclosure of listed companies, the lower the price of the shares will be traded, thereby reducing the cost of financing and transaction costs.Bloomfield and Wilks (2000) studied the relationship between information disclosure and financing costs, it is found that the level of information disclosure has a positive effect on the stock price and the market liquidity.Therefore, based on the above discussion, we can make the following assumptions:

H1: the higher the quality of internal control information disclosure, the lower the cost of equity financing.

The Relationship between Internal Control Quality and Corporate Debt Financing Cost. Kim J.B.Song,B. YZhang found that companies with major defects and internal control deficiencies 
at the firm level are more likely to have higher debt financing costs than those with less internal control deficiencies.Fang Hongxing, Zhang Zhiping (2012) believes that strengthening the internal control of enterprises, can help improve the level of corporate governance and self supervision, effectively prevent fraud and fraud.This is not only to improve the operating performance of the enterprise, but also to the external transfer of a good business, good performance, good long-term stability of the signal.

Better quality control of the internal control of the company, will have the opportunity to give priority to debt funds, debt financing in specific terms such as financing costs will also have more favorable conditions.Based on the above analysis, this paper proposes second hypotheses:

$\mathrm{H} 2$ : the higher the quality of internal control information disclosure, the lower the cost of debt financing.

\section{Research Design}

Sample Selection and Data Sources. Select the Shanghai and Shenzhen A-share listed companies in 2013-2015 as the research object, and on this basis, in accordance with the following order to eliminate:

a. because of the industry environment of the financial industry is different from other industries;

b. excluding financial information and internal control index and other basic information of listed companies;

The company's main source of financial data in the CSMAR database, the internal control index from Shenzhen Dibo Enterprise Risk Management Technology Co. Ltd., internal control and risk management database.

Variable Selection. Explained variabl—equity financing costs

With regard to the measurement of the cost of equity financing, this paper uses PEG estimation model to estimate the cost of equity financing. The PEG model is mainly used in Li Chao (2011) in the study of the cost of equity capital.Compared with GLS model and KR model, the equity financing cost calculated by PEG model is more reliable and more suitable for Chinese capital market.

Estimation formula of equity cost:RPEG $=\sqrt{ }$ (eps 2 - eps1)/po

Among them, RPEG: equity capital costs,eps2: expected second period earnings per share,eps1: expected first period earnings per share,po: zero period per share price.

Debt financing costs-The cost of debt capital is the cost of borrowing and issuing bonds, including interest and financing charges on borrowings or bonds.Using interest rate as a measure of the cost of debt capital.To study the relationship between the debt cost and the quality of internal control by using interest expense / average annual (long term loan + short term loan).

Explanatory Variables. To study the correlation between internal control quality and debt financing,this paper use the internal control index which from Shenzhen Dibo Enterprise Risk Management Technology Co. Ltd., internal control and risk management database takes the natural logarithm to measure the internal control quality (ICI). The higher the index, the higher the quality of internal control of listed companies.

Control Variable. Financial leverage (Lev) — How much of the total assets are financed through liabilities,also measure the degree of protection of creditors in bankruptcy liquidation.From the perspective of creditors, the lower the debt ratio the better, the company has a debt guarantee, low lending risk; from the debtor's point of view, in order to maximize the profit, the higher the ratio of the total capital profit rate, the higher the debt ratio.

Book to market ratio (B/M) - Gebhardt. Lee and Swaminathan (2001) after the study found that 
the market tends to underestimate the book market ratio of the company's share price, investors to invest in this kind of company will often get more income, less risk, so the required rate of return is low.The creditors are also on the future earnings also reduced uncertainty, and thus relatively relaxed debt conditions, and the company, the debt financing costs.

Profit level (Roa) - Using Roa to measure the amount of net profit per unit of assets to create an index, in general, the higher the total return on assets, indicating that the company's profitability stronger.For creditors, the company's profitability is good, that the company's solvency in the future period of protection, default risk is small, debt financing costs will be lower.

Growth (Growth) - Gebhardt, Lee and Swaminathan (2001) the results of the study show that in the growth period of enterprises will face greater risks and bankruptcy costs to compensate for the uncertainty of future earnings, investors tend to demand higher returns. Therefore, the growth rate of business income is used to measure the growth of enterprises.

Company size (Size)-Generally speaking, the larger enterprises have a set of system management mode, the ability to respond to risks and the ability to resist risks is also strong.As a result, investors and creditors are more willing to support larger firms than smaller ones, thus reducing the cost of financing.

Table 1 Variable description

\begin{tabular}{|c|c|c|c|c|}
\hline $\begin{array}{l}\text { Variable } \\
\text { type }\end{array}$ & Variable name & $\begin{array}{l}\text { Variable } \\
\text { symbol }\end{array}$ & Variable definition and value & $\begin{array}{c}\text { Prediction } \\
\text { direction }\end{array}$ \\
\hline \multirow{2}{*}{$\begin{array}{c}\text { depende } \\
\text { nt } \\
\text { variable }\end{array}$} & $\begin{array}{c}\text { Equity } \\
\text { financing cost }\end{array}$ & $\mathrm{R}$ & PEG model & \\
\hline & $\begin{array}{l}\text { Debt financing } \\
\text { cost }\end{array}$ & $\mathrm{C}$ & $\begin{array}{l}\text { The ratio of interest expense to the sum of } \\
\text { long-term and short-term borrowings }\end{array}$ & \\
\hline $\begin{array}{c}\text { independ } \\
\text { ent } \\
\text { variable }\end{array}$ & $\begin{array}{l}\text { Internal control } \\
\text { quality }\end{array}$ & ICI & $\begin{array}{l}\text { The natural logarithm of the internal control } \\
\text { evaluation index from Shenzhen Dibo }\end{array}$ & $\begin{array}{l}\text { negative } \\
\text { correlation }\end{array}$ \\
\hline \multirow{5}{*}{$\begin{array}{c}\text { control } \\
\text { variable }\end{array}$} & $\begin{array}{c}\text { Financial } \\
\text { leverage ratio }\end{array}$ & Lev & $\begin{array}{l}\text { Percentage of total liabilities at the end of } \\
\text { the year divided by total assets }\end{array}$ & $\begin{array}{l}\text { positive } \\
\text { correlation }\end{array}$ \\
\hline & book-to-market & $\mathrm{B} / \mathrm{M}$ & $\begin{array}{l}\text { Book value / market value at the end of the } \\
\text { year }\end{array}$ & $\begin{array}{l}\text { positive } \\
\text { correlation }\end{array}$ \\
\hline & Profit level & Roa & $\begin{array}{l}\text { Gross profit plus interest expense / total } \\
\text { assets }\end{array}$ & $\begin{array}{c}\text { negative } \\
\text { correlation }\end{array}$ \\
\hline & $\begin{array}{l}\text { Growth } \\
\text { property }\end{array}$ & Growth & Revenue growth over the years & $\begin{array}{l}\text { positive } \\
\text { correlation }\end{array}$ \\
\hline & company size & Size & Natural logarithm of total assets & $\begin{array}{l}\text { negative } \\
\text { correlation }\end{array}$ \\
\hline
\end{tabular}

\section{Model Building}

Research Model of Internal Control Information Quality and Equity Financing Cost. In the study of the relationship between the quality of internal control information disclosure and the cost of equity financing.Many research results show that the factors such as firm size, book to market ratio, profitability and other factors will affect the cost of equity financing. Therefore, in the study of the quality of internal control information disclosure and the cost of equity financing, the paper still controls the above variables, using multiple regression method. 


\section{Model one $: R=\alpha+\beta 1 \mathrm{ICI}+\beta 2 \mathrm{Lev}+\beta 3 \mathrm{~B} / \mathrm{M}+\beta 4 \mathrm{Roa}+\beta 5 \mathrm{Growth}+\beta 6 \mathrm{Size}+\mathcal{E}$}

Research Model of Internal Control Information Quality and Debt Financing Cost. Many factors affect the cost of debt financing,many researches found that the better the operating conditions, the larger the size of the company, the lower the cost of corporate debt, the main business revenue growth and profitability of the stronger companies, the lower the total cost of debt.Based on this, the book to market ratio, the company size, profitability, growth and other variables as control variables.

Model two: $C=\alpha+\beta 1 \mathrm{ICI}+\beta 2 \mathrm{Lev}+\beta 3 \mathrm{~B} / \mathrm{M}+\beta 4 \mathrm{Roa}+\beta 5 \mathrm{Growth}+\beta 6 \mathrm{Size}+\varepsilon$

\section{Empirical Analysis}

\section{Descriptive Statistical Analysis}

Table 2 Descriptive statistics of model one and model two

\begin{tabular}{|c|c|c|c|c|c|}
\hline & $\mathrm{N}$ & Minimum value & maximum value & mean value & standard deviation \\
\hline $\mathrm{R}$ & 2596 & 0.060 & 0.4570 & 0.195163 & 0.0851194 \\
$\mathrm{C}$ & 2596 & 0.013 & 0.6774 & 0.063028 & 0.0902095 \\
$\mathrm{ICI}$ & 2596 & 3.4217 & 6.9031 & 6.512947 & 0.1394032 \\
Lev & 2596 & 0.0260 & 1.0361 & 0.500571 & 0.1891018 \\
$\mathrm{~B} / \mathrm{M}$ & 2596 & 0.6992 & 15.0649 & 1.861941 & 1.0360842 \\
Roa & 2596 & -0.1133 & 0.3809 & 0.044049 & 0.0343639 \\
Growth & 2596 & -0.8114 & 367.5320 & 0.511401 & 10.0821515 \\
Size & 2596 & 19.0811 & 28.4820 & 22.237143 & 1.3139979 \\
Valid N (list status) & 2596 & & & & \\
\hline
\end{tabular}

Results from the table above can be found,the cost of equity financing of listed companies reached 0.457 , while the lowest is only 0.060 , the difference between the cost of financing showed different listed companies is relatively large, and the greater the cost of debt financing gap, the highest value is 0.677 , the minimum value is only 0.013 , a difference of 52 times. In terms of internal control quality index, the minimum value is 3.422 , the maximum value is 6.903 , the standard deviation is about 0.139 .It can be seen that there are obvious differences in the quality of internal control information of listed companies.

In the aspect of control variables, the ratio of asset liability ratio is low, which indicates that the proportion of debt financing of listed companies is low. The cost of equity financing, asset liability ratio of the standard deviation is less than 0.2 , which shows that it has good stability and concentration; growth rate and the asset size of the standard deviation is greater than 1, it said that for these two indicators, the difference between companies obviously. In particular, the growth rate, the standard deviation of up to 10.082 , the maximum value of the minimum value of -0.811 is 367.532 , the difference between the growth rate of the larger companies. This is because at the time of research, did not rule out abnormal data.

Pearson Correlation Analysis. Because there are many factors that affect the cost of equity financing and debt financing.In this paper, some of the factors are selected as variables, and these variables will have the possibility of multicollinearity. In the internal control quality and equity financing costs and the cost of debt financing regression analysis, first of all the two models of the 
possible correlation between the variables to do a preliminary test, if there is a tendency of multicollinearity between the two indexes, the relationship between variables can not be explained. The results show that if the Pearson correlation coefficient is more than 0.9 variables, there exists multicollinearity problem, and more than 0.8 indicates that there may be a collinearity problem. The results is shown in Table 3 and Table 4:

Table 3 Correlation test of model one

\begin{tabular}{|c|c|c|c|c|c|c|c|c|}
\hline & & $\mathrm{R}$ & ICI & Lev & $\mathrm{B} / \mathrm{M}$ & Roa & Growth & Size \\
\hline \multirow[t]{2}{*}{$\mathrm{R}$} & $\begin{array}{c}\text { Pearson correlation } \\
\text { Significant } \\
\text { (bilateral) }\end{array}$ & 1 & & & & & & \\
\hline & $\mathrm{N}$ & 2596 & & & & & & \\
\hline \multirow[t]{3}{*}{ ICI } & Pearson correlation & $-0.092^{*}$ & 1 & & & & & \\
\hline & $\begin{array}{c}\text { Significant } \\
\text { (bilateral) }\end{array}$ & 0.038 & & & & & & \\
\hline & $\mathrm{N}$ & 2596 & 2596 & & & & & \\
\hline \multirow[t]{3}{*}{ Lev } & Pearson correlation & 0.004 & -0.015 & 1 & & & & \\
\hline & $\begin{array}{l}\text { Significant } \\
\text { (bilateral) }\end{array}$ & 0.749 & 0.230 & & & & & \\
\hline & $\mathrm{N}$ & 2596 & 2596 & 2596 & & & & \\
\hline \multirow[t]{3}{*}{$\mathrm{B} / \mathrm{M}$} & Pearson correlation & $.126^{* *}$ & $-0.032^{*}$ & $-0.109^{* *}$ & 1 & & & \\
\hline & $\begin{array}{l}\text { Significant } \\
\text { (bilateral) }\end{array}$ & .000 & 0.012 & .000 & & & & \\
\hline & $\mathrm{N}$ & 2596 & 2596 & 2596 & 2596 & & & \\
\hline \multirow[t]{3}{*}{ Roa } & Pearson correlation & -0.002 & 0.005 & -0.012 & 0.017 & 1 & & \\
\hline & $\begin{array}{c}\text { Significant } \\
\text { (bilateral) }\end{array}$ & 0.849 & 0.683 & 0.330 & 0.182 & & & \\
\hline & $\mathrm{N}$ & 2596 & 2596 & 2596 & 2596 & 2596 & & \\
\hline \multirow[t]{3}{*}{ Growth } & Pearson correlation & $0.296^{* *}$ & 0.003 & 0.011 & -0.001 & 0.001 & 1 & \\
\hline & $\begin{array}{c}\text { Significant } \\
\text { (bilateral) }\end{array}$ & .000 & 0.807 & 0.378 & 0.929 & 0.957 & & \\
\hline & $\mathrm{N}$ & 2596 & 2596 & 2596 & 2596 & 2596 & 2596 & \\
\hline \multirow[t]{3}{*}{ Size } & Pearson correlation & $-0.126^{*}$ & $0.364^{* *}$ & $0.424^{* *}$ & $-0.207^{* *}$ & $-0.038^{* *}$ & -0.003 & 1 \\
\hline & $\begin{array}{l}\text { Significant } \\
\text { (bilateral) }\end{array}$ & 0.049 & .000 & .000 & .000 & 0.002 & 0.786 & \\
\hline & $\mathrm{N}$ & 2596 & 2596 & 2596 & 2596 & 2596 & 2596 & 2596 \\
\hline
\end{tabular}

**. Significant correlation at 0.01 level (bilateral).

*. significant correlation at 0.05 levels (bilateral) 
Table 4 Correlation test of model two

\begin{tabular}{|c|c|c|c|c|c|c|c|c|}
\hline & & $\mathrm{C}$ & ICI & Lev & $\mathrm{B} / \mathrm{M}$ & Roa & $\begin{array}{c}\text { Growt } \\
\mathrm{h}\end{array}$ & Size \\
\hline \multirow[t]{2}{*}{$\mathrm{C}$} & $\begin{array}{c}\text { Pearson correlation } \\
\text { Significant } \\
\text { (bilateral) }\end{array}$ & 1 & & & & & & \\
\hline & $\mathrm{N}$ & 2596 & & & & & & \\
\hline \multirow[t]{2}{*}{ ICI } & $\begin{array}{c}\text { Pearson correlation } \\
\text { Significant } \\
\text { (bilateral) }\end{array}$ & $\begin{array}{l}-0.131 \\
0.019^{*}\end{array}$ & 1 & & & & & \\
\hline & N & 2596 & 2596 & & & & & \\
\hline \multirow[t]{2}{*}{ Lev } & $\begin{array}{c}\text { Pearson correlation } \\
\text { Significant } \\
\text { (bilateral) }\end{array}$ & $\begin{array}{l}0.222^{* *} \\
0.000\end{array}$ & $\begin{array}{l}0.026 \\
0.190\end{array}$ & 1 & & & & \\
\hline & $\mathrm{N}$ & 2596 & 2596 & 2596 & & & & \\
\hline \multirow[t]{3}{*}{$\mathrm{B} / \mathrm{M}$} & Pearson correlation & -0.008 & -0.016 & $-0.354^{* *}$ & 1 & & & \\
\hline & $\begin{array}{l}\text { Significant } \\
\text { (bilateral) }\end{array}$ & 0.688 & 0.409 & 0.000 & & & & \\
\hline & $\mathrm{N}$ & 2596 & 2596 & 2596 & 2596 & & & \\
\hline \multirow[t]{3}{*}{ Roa } & Pearson correlation & $-0.068^{* *}$ & -0.003 & $-0.419^{* *}$ & $0.437^{* *}$ & 1 & & \\
\hline & $\begin{array}{l}\text { Significant } \\
\text { (bilateral) }\end{array}$ & 0.001 & 0.862 & 0.000 & 0.000 & & & \\
\hline & $\mathrm{N}$ & 2596 & 2596 & 2596 & 2596 & 2596 & & \\
\hline \multirow[t]{3}{*}{ Growth } & Pearson correlation & 0.007 & 0.003 & $0.049^{*}$ & 0.026 & -0.009 & 1 & \\
\hline & $\begin{array}{c}\text { Significant } \\
\text { (bilateral) }\end{array}$ & 0.716 & 0.866 & 0.013 & 0.193 & 0.652 & & \\
\hline & $\mathrm{N}$ & 2596 & 2596 & 2596 & 2596 & 2596 & 2596 & \\
\hline \multirow[t]{3}{*}{ Size } & Pearson correlation & $-0.058^{* *}$ & 0.031 & $0.510^{* *}$ & $-0.429^{* *}$ & $-\underset{*}{-0.053^{*}}$ & -0.036 & 1 \\
\hline & $\begin{array}{l}\text { Significant } \\
\text { (bilateral) }\end{array}$ & 0.003 & 0.110 & 0.000 & 0.000 & 0.006 & 0.065 & \\
\hline & $\mathrm{N}$ & 2596 & 2596 & 2596 & 2596 & 2596 & 2596 & 2596 \\
\hline
\end{tabular}

**. Significant correlation at 0.01 level (bilateral).

*. significant correlation at 0.05 levels (bilateral)

It can be seen from the table,the correlation coefficient of internal control quality index ICI and equity financing cost $\mathrm{R}$ and bond financing cost $\mathrm{C}$ are negative. It shows that there is a significant negative correlation between them, that is, the quality of internal control is good, the cost of equity financing and bond financing is lower.The hypothesisone and two is verified preliminarily.

Multiple regression analysis. After a preliminary test of the correlation between the variables of model one and model two, the two models were analyzed by multiple regression.First of all, according to the model, considering the various control variables, the relationship between the equity financing cost and the quality of internal control of listed companies is further tested: 
Table 5 Multiple linear regression of model one

\begin{tabular}{|c|c|c|c|c|c|c|}
\hline & \multirow[t]{2}{*}{ Model } & \multicolumn{2}{|c|}{ Non standardized coefficient } & \multirow{2}{*}{$\frac{\text { Standard coefficient }}{\text { Beta }}$} & \multirow[t]{2}{*}{$\mathrm{t}$} & \multirow[t]{2}{*}{ Sig. } \\
\hline & & B & Standard error & & & \\
\hline \multirow{7}{*}{1} & (constant) & 0.093 & 0.056 & & 1.651 & $0.099 *$ \\
\hline & ICI & -0.017 & 0.008 & -0.028 & -2.151 & $0.032 * *$ \\
\hline & Lev & 0.007 & 0.008 & 0.015 & 0.876 & 0.381 \\
\hline & $\mathrm{B} / \mathrm{M}$ & 0.001 & 0.000 & 0.040 & 2.849 & $0.004 * * *$ \\
\hline & Roa & 0.669 & 0.034 & 0.301 & 19.941 & $0.000 * * *$ \\
\hline & Growth & 0.0008928 & 0.000 & 0.007 & 0.509 & 0.611 \\
\hline & Size & -0.002 & 0.001 & -0.031 & -1.937 & $0.053^{*}$ \\
\hline
\end{tabular}

a.Dependent variable:equity financing cost

b. *. Statistically significant at $0.1 ;^{* *}$.Statistically significant at $0.05 ; * *$. Statistically significant at 0.01 .

In the model one, the relationship between the quality of internal control and the cost of equity financing is analyzed by controlling leverage ratio, book value, firm size, profitability and growth. Can be learned from the table, the quality of internal control and the cost of equity financing is negatively related to the internal control, the better the quality of the company, the cost of equity financing is lower; on the contrary, the lower the quality of the internal control of the enterprise, the cost of equity capital will be higher.Moreover, the equation has been shown to be significant at $5 \%$ confidence level, that is, the hypothesis one is verified.

Table 6 Multiple linear regression of model two

\begin{tabular}{|c|c|c|c|c|c|}
\hline \multirow{2}{*}{ Model } & \multicolumn{2}{|c|}{ Non standardized coefficient } & Standard coefficient & $\mathrm{t}$ & \multirow{2}{*}{ Sig. } \\
\cline { 2 - 4 } & $\mathrm{B}$ & Standard error & Beta & & \\
\hline \multirow{2}{*}{ (constant) } & 0.245 & 0.083 & & 2.967 & $0.003^{* * *}$ \\
ICI & -0.021 & 0.012 & -0.035 & -1.832 & $0.047^{* *}$ \\
Lev & 0.127 & 0.011 & 0.283 & 11.297 & $0.000^{* * *}$ \\
2 & 0.005 & 0.002 & 0.057 & 2.379 & $0.017^{* *}$ \\
B/M & 0.055 & 0.059 & 0.022 & 0.927 & 0.354 \\
Roa & -0.0008 .421 & 0.000 & -0.010 & -0.521 & 0.603 \\
Growth & -0.004 & 0.002 & -0.060 & -2.393 & $0.017^{* *}$ \\
\hline
\end{tabular}

a.Dependent variable: debt financing

b.*.Statistically significant at $0.1{ }^{* *}$.Statistically significant at $0.05 ; * *$. Statistically significant at 0.01 .

In model 2, there is a significant negative correlation between internal control quality and corporate debt financing cost, and it is significant at 5\% confidence level, which verifies the hypothesis two.Therefore, the better the quality of internal control, the lower the cost of debt financing; on the contrary, the worse the quality of internal control, the higher the cost of debt financing. 


\section{Conclusions}

The results of empirical research fully illustrate that the sources of funding for the company-investors and creditors still pay more attention to the quality of internal control of an enterprise.Internal control quality is negatively related to corporate financing cost.Through the significance test, we can conclude that the higher the quality of internal control, the lower the cost of equity financing, the lower the cost of debt financing.Improve the quality of internal control is conducive to reduce the cost of corporate finance, it also shows that the internal control information disclosure is the content of information, it conveys a signal to the market, investors have to a certain extent on the quality of internal control information disclosure of different companies to treat.

For investors, creditors and corporate management,good internal control will reduce the asymmetry of information, reduce agency costs and achieve win-win situation for the three party.For regulators, the attitude of investors and creditors greatly promoted the construction and improvement of the internal control system,not only contribute to the growth of enterprises, enhance the ability of sustainable development of enterprises, more conducive to regulate the behavior of the entire market.

\section{References}

[1] Fang Hong Xing, Zhang Zhiping. Internal control quality and Accounting Conservatism: Empirical Evidence from the annual report of A shares of Shenzhen Stock Exchange [J]. 2007-2010 audit and economic research, 2012, (09):3-10.

[2] Li Xiaohui, Yang Zixuan.Research on the quality of internal control and the protection of creditors -- Based on the perspective of debt contract [J].Auditing and economic research, 2013, (02):97-105.

[3] Healy and Palepu.Information asymmetry,corporate disclosure,and the capitalmarkets: A review of the empirical disclosure literature. Journal of Accounting \&Economics. 2001, (31):405-440.

[4] Bloomfield,R.and Wilks.T. Disclosure effects in the laboratory: liquidity,depth,and the cost of capital. The Accounting Review.2000,(1):13-41.

[5] Kim,J.B.Song,B.YZhang,L.Internal Control Weakness and Bank Loan Contracting: Evidence from SOX Section 404 Disclosure. The Accounting Review,2011, 86(4):1157-1188.

[6] Li Chao.Reliability test of equity capital cost estimation [J].Journal of Shanghai Finance University, 2011, (5):78 87.

[7] Internal control index of Xiamen University.2010.Chinese listed companies internal control index (2009): formulation, analysis and evaluation.China Securities Journal, 2010-06-11:A21.

[8] Wang Hong, Jiang Zhanhua, Hu min, 2011.Research on internal control index of Chinese Listed Companies The first edition Beijing: People's publishing house, 42-94.

[9] Gebhardt,Lee,Swaminathan,Toward an Implied Cost of Capital.Journal of Accounting Research. 2001, (1):135-175. 